\title{
Mekanisme Bagi Hasil pada Sistem Affiliate Marketing Taqychan Saffron
}

\author{
Isra Misra' ${ }^{1}$ Zakiah $^{2}$, \& Enriko Tedja Sukmana ${ }^{3}$ \\ 1 Institut Agama Islam Negeri Palangkaraya, Indonesia. E-mail: isra.misra@iain-palangkaraya.ac.id \\ 2 Institut Agama Islam Negeri Palangkaraya, Indonesia. E-mail: zakian@gmail.com \\ 3 Institut Agama Islam Negeri Palangkaraya, Indonesia. E-mail: enrico@iain-palangkaraya.ac.id
}

\section{ARTICLE INFO}

Keywords:

Affiliate Marketing; Profit Sharing; Taqychan Saffron

Kata Kunci:

Affiliate Marketing; Bagi Hasil; Taqychan Saffron

\section{ABSTRACT}

Affiliate marketing is a business model with a fee or commission system for someone's services, after that person has successfully sold goods or services through marketing on the Internet. The purpose of this study was to identify and analyze the profit-sharing mechanism for members of Taqychan Saffron in Palangka Raya. This study uses a qualitative descriptive approach, with triangulation of sources as data validity. The research subjects are members of Taqychan Saffron who have been registered for more than 1 year with 5 research subjects. Data analysis was carried out by collecting data, collecting data, reducing data and drawing conclusions. The results showed that the profit sharing for Taqychan Saffron members was carried out using a commission and royalty system. Sales of each Taqychan Saffron product will get a 15\% commission and 5\% royalty bonus from members who have been recruited and they are actively selling. The contract uses a murabaha contract that is agreed upon online on the Taqychan Saffron website. This business pays for services by spreading a link or referral code from the company's website. Currently, many online business activities like this have been carried out and are in accordance with the MUI fatwa regarding the permissibility of conducting e-commerce transactions.

\section{ABSTRAK}

Affiliate marketing adalah model bisnis dengan sistem pemberiaan fee atau komisi untuk jasa seseorang, setelah orang tersebut berhasil menjualkan barang atau jasa melalui pemasaran di Internet. Tujuan penelitian ini adalah mengetahui dan menganalisis mekanisme bagi hasil pada member Taqychan Saffron di Palangka Raya. Penelitian ini menggunakan pendekatan deskriptif kualitatif, dengan triangulasi sumber sebagai validitas data. Subyek penelitian adalah member Taqychan Saffron yang telah terdaftar lebih dari 1 tahun dengan subyek penelitian sebanyak 5 orang. Analisis data dilakukan dengan pengumpulan data, koleksi data, reduksi data dan pengambilan kesimpulan. Hasil penelitian menunjukkan bahwa bagi hasil pada member Taqychan Saffron dilakukan dengan system komisi dan royalty. penjualan setiap produk Taqychan Saffron akan mendapatkan komisi $15 \%$ dan $5 \%$ bonus royalti dari member yang telah direkrut dan mereka aktif berjualan. Akad menggunakan akad murabahah yang disepakati secara online pada website Taqychan Saffron. Bisnis ini 
membayar jasa dengan cara menyebarkan link atau kode referral dari website perusahaan tersebut. Pada saat ini kegiatan bisnis online seperti ini telah banyak dilakukan dan sesuai dengan fatwa MUI tentang bolehnya melakukan kegiatan transaksi e-commerce.

\section{Pendahuluan}

Manusia merupakan makhluk sosial yang diciptakan oleh Allah sebagai khalifah di muka bumi. Peran mansuia tidak lain adalah memberikan kemanfaatan bagi makhluk lain baik sesama manusia maupun tumbuhan dan hewan. Peran manusia sebagai makhluk sosial tidak lain dan tidak bukan adalah menjadi manusia yang senang melakukan kebaikan dengan tolong menolong (ta'awun) dan saling bertukar barang dan jasa sehingga saling membutuhkan satu sama lain. ${ }^{1}$

Pada abad ke- 21 ini manusia mengalami kemajuan peradaban yang sangat pesat. Pengaruh globalisasi begitu terasa mulai dari wilayah perkotaan maupun pelosok pedesaan. Kemajuan tekhnologi membuat manusia semakin dinamis dan mampu melahirkan alternatif bisnis dengan prospek yang besar. ${ }^{2}$ Tidak luput dari itu kegiatan berbelanjapun telah berubah dari kegiatan transaksi secara tradisional berubah menggunakan tekhnologi secara virtual (online). Berbelanja secara online sudah tentu memberikan kemudahan bagi konsumen. ${ }^{3}$ Bisnis online yang menggunakan jejaring sosial (sosial media) mampu menghadirkan transaksi dan dapat dilakukan oleg siapa pun dan dimana pun dengan penuh kemudahan. ${ }^{4}$ Kegiatan bisnis yang di dukung oleh internet mampu menghubungkan seluruh manusia di dunia dari belahan dunia lain tanpa harus mengenal satu dengan yang lain. ${ }^{5}$

Kemajuan teknologi dan informasi masa ini berdampak pada meningkatnya penggunaan internet untuk kegiatan bisnis. ${ }^{6}$ Diantara yang menggunakan media

\footnotetext{
${ }^{1}$ Isra Misra and Ali Sadikin, “NILAI-NILAI EKONOMI ISLAM DALAM TRADISI MALAN" 17, no. 01 (2021): 72-82, https://doi.org/10.23971/jsam.v.

${ }^{2}$ Ali Sadikin dan Muhammad sholehuddin Isra Misra, Pengantar Manajemen Dan Bisnis (Yogyakarta: K-Media Publiser, 2020).

${ }^{3}$ Reminta Lumban Batu et al., "Pengaruh Digital Marketing Terhadap Online Purchase Decision Pada Platform Belanja Online Shopee," Ekonomi \& Bisnis 18, no. 2 (2020): 144-52, https://doi.org/10.32722/eb.v18i2.2495.

${ }^{4}$ Barbora Benediktova and Lukas Nevosad, "MASTER'S THESIS Affiliate Marketing Perspective of Content Providers," 2008.

${ }^{5}$ Isra \& Arianto Misra, “Pengaruh Dimensi Kualitas Pelayanan Jasa Terhadap Kepuasan Dan Minat Datang Kembali Konsumen Pada Dealer Wira Megah Toyota Profitamas Palangka Raya Isra Misra 1," Al-Qard Vol 3, no. 1 (2018): 1-12, https://e-journal.iainpalangkaraya.ac.id/index.php/qardh/article/view/1181.

${ }^{6}$ Benediktova and Nevosad, "MASTER'S THESIS Affiliate Marketing Perspective of Content Providers."
} 
tersebut adalah system pemasaran yang biasa disebut dengan affiliate marketing. ${ }^{7}$ Konsep affiliate marketing merupakan system pemasaran dengan menggunakan internet yang menghubungkan pembeli, perantara dan pemilik barang. Model yang digunakan dalam system bisnis ini tidak lain adalah menerapkan prinsip jual beli barang dan jasa berbasis komisi. ${ }^{8}$

Ada beberapa perusahaan yang menjalankan model bisnis affiliate marketing, salah satunya bisnis yang dikelola langsung oleh seorang tokoh publik Taqy Malik yaitu Taqychan Saffron. Taqychan Saffron ini merupakan pelopor pertama Saffron Kashmir. Saffron Kashmir ini dipetik langsung dari kebun Pampore, di Kashmir India Utara.

Beberapa perusahaan yang menerapkan system affiliate marketing salah satunya adalah tokoh public dari Kalimantan Selatan yakni Taqy Malik dengan brand Taqychan Saffron. Taqychan Saffron merupakan perusahaan yang menjadi pelopor pertama saffron Kashmir. Saffron merupakan bunga yang sering digunakan untuk hidangan chef dan alat kecantikan yang dipetik langsung dari Pampore Kashmir India Utara.

\section{Landasan Teori}

Strategi internet marketing yang paling sering dilakukan oleh para pemilik produk adalah affiliate marketing (afiliasi pemasaran). Menurut Prayitno, affiliate marketing merupakan sistem komisi yang diberikan kepada seseorang yang berhasil merekomendasikan produk tersebut kepada orang lain. ${ }^{9}$ Affiliate marketing adalah cara untuk memperoleh penghasilan berupa komisi dengan cara menjual barang melalui situs. Situs affiliate akan memiliki link-link yang terhubung dengan situs pemilik barang. ${ }^{10}$

Affiliate marketing adalah cabang dari kajian ilmu pemasaran. ${ }^{11}$ Pemasaran yang terlihat dari bauran pemasaran bahwa affiliate dilakukan dengan pendekatan promosi yang dilakukan melalui jaringan internet. ${ }^{12}$ Pemasaran yang mengutamakan komisi tidak lain adalah strategi manajemen dalam menarik membership sehingga

\footnotetext{
${ }^{7}$ Zurina Patrick and Ong Choon Hee, "Affiliate Marketing in SMEs: The Moderating Effect of Developmental Culture," Pertanika Journal of Social Sciences and Humanities 29, no. 2 (2021): 124971, https://doi.org/10.47836/pjssh.29.2.27.

${ }^{8}$ Anita Rahmawaty, “Bisnis Multilevel Marketing Dalam Perspektif Islam," Marketing, 2013, 77-94.

${ }^{9}$ Ahmad Muhamim, "Analisis Strategi Affiliate Marketing Terhadap Tingkat Penjualan Dalam Perspektif Ekonomi Islam(Studi Pada Butik Zoya Cabang Kedaton Bandar Lampung)," 2017, http://repository.radenintan.ac.id/319/.

${ }^{10}$ Desrini Ningsih, “Analisis Promosi Dan Affiliasi Marketing Terhadap Okupansi Hotel Non Jaringan Di Kota Batam" 8, no. 1 (2019): 125-34.

11 James R Situmorang, "Pemasaran Viral Â€” Viral Marketing," Jurnal Administrasi Bisnis Unpar 6, no. 1 (2010): 63-75, https://doi.org/10.26593/jab.v6i1.369.

12 Patrick and Hee, "Affiliate Marketing in SMEs: The Moderating Effect of Developmental Culture."
} 
taqychan saffron bisa lebih dikenal. Pendekatan ini hampir mirip dengan pendekatan multi level marketing (MLM) namun lebih kepada komisi secara langsung. ${ }^{13}$

Secara umum affiliate marketing adalah suatu cara dimana agen menjualkan produk orang lain dan akan mendapatkan komisi jika terjadi pembelian melalui referensinya. ${ }^{14}$ Atas dasar tersebut pemasar jasa tidak perlu memikirkan stok atau persediaan, tetapi yang pemasar jasa pikirkan adalah hanya mengarahkan pengunjung ke website melalui link khusus yang pemasar miliki. ${ }^{15}$ Link ini akan didapatkan dari merchant sebagai alat untuk mendeteksi bahwa pembeli yang datang adalah melalui referensi pemasar jasa tersebut. ${ }^{16}$

Islam tidak membatasi manusia dalam bermuamalah. ${ }^{17}$ Begitu juga dengan konsep pemasaran online apabila dilakukan dengan tetap menerapkan prinsip Islam maka kegiatan itu boleh saja dilakukan. ${ }^{18}$ Ulama terkemuka seperti Assil Alhakim mengatakan bahwa affiliate marketing atau pemasaran online akan menjadi halal apabila dilakukan dengan syariat yang telah digariskan oleh Islam dengan melakukan promosi produk yang telah jelas kehalalannya dan jujur dalam menyampaikan informasi dari produk tersebut. ${ }^{19}$ Firman Allah dalam surat Annisa tentang larangan untuk mengambil harta yang bukan hak dengan cara yang tidak jujur sebagai berikut: ${ }^{20}$

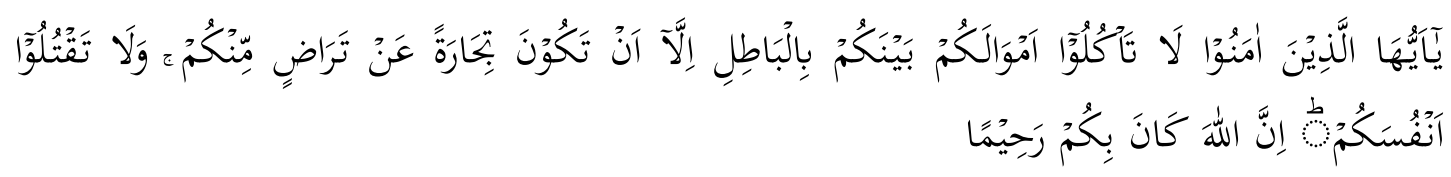

Artinya: "Hai orang-orang yang beriman, janganlah kamu saling memakan harta sesamamu dengan jalan yang batil, kecuali dengan jalan perniagaan yang berlaku dengan suka sama suka diantara kamu."

Konsep penjualan online ini melibatkan pemilik barang, perantara, dan pembeli dalam transaksi penjualan barang di dunia maya. Model bisnis ini menerapkan

\footnotetext{
${ }^{13}$ Rahmawaty, "Bisnis Multilevel Marketing Dalam Perspektif Islam."

${ }^{14}$ Benediktova and Nevosad, "MASTER'S THESIS Affiliate Marketing Perspective of Content Providers."

15 Jurnal Ekonomi, Hukum Ekonomi, and Masyarakat Membeli Sukuk, "AL-IQTISHADIYAH” 6 (2020).

${ }^{16}$ Muhamim, “ANALISIS STRATEGI AFFILIATE MARKETING TERHADAP TINGKAT PENJUALAN DALAM PERSPEKTIF EKONOMI ISLAM(Studi Pada Butik Zoya Cabang Kedaton Bandar Lampung).”

${ }^{17}$ Muhammad Ragil dan Muhammad Iqbal Isra Misra, Manajemen Perbankan Syariah (Yogyakarta: KMedia Publiser, 2021).

${ }^{18}$ Ron Mandelbaum and Amos Zehavi, "Recession as a Window of Opportunity for Public Sector Recruitment," Policy Studies 35, no. 2 (2014): $115-30$, https://doi.org/10.1080/01442872.2013.875142.

${ }^{19}$ Nur Rianto, Dasar-Dasar Ekonomi Islam (Solo: Era Adicitra Intermedia, 2017).

${ }^{20}$ Departemen Agama RI, Al-Qur'an Dan Terjemahnya (Jakarta: Proyek Pengadaan Kitab Suci Al-Quran KEMENAG, 2015).
} 
prinsip untuk menjual barang dan jasa berbasis komisi. ${ }^{21} \mathrm{Hal}$ utama yang harus dimiliki oleh affiliate marketer adalah situs untuk mempromosikan produk-produk yang telah dipilih dari affiliate merchant atau vendor pemilik barang. ${ }^{22}$

Tujuan dari adanya afiliasi adalah untuk mempromosikan produk/jasanya menjadi lebih luas lagi tanpa batasan selama masih di dunia online Internet. Dengan kata lain pemilik website memerlukan sejumlah tenaga penjual untuk membantunya menjual produk. ${ }^{23}$

Bisnis affiliasi tidak hanya untuk mereka yang sudah mahir di bisnis online, namun juga direkomendasikan untuk kalangan pemula. ${ }^{24} \mathrm{Hal}$ ini terjadi karena bisnis afiliasi adalah kegiatan yang relatif tidak susah dilakukan yaitu tanpa membuat produk pemasar sudah bisa mengasah kemampuan penjualan di media sosial maupun media internet. ${ }^{25}$ Dalam affiliate marketing pemasar dituntut untuk mampu mendatangkan calon pembeli ke website merchant. ${ }^{26}$ Dengan cara apapun anda harus mampu mendatangkan banyak calon pembeli dimana jika pemasar mendatangkan banyak calon pembeli maka jika pemasar sudah berpengalaman dan tahu cara mendatangkan traffic tersebut maka pemasar pasti akan menguasai kunci dari bisnis online secara berkesinambungan. ${ }^{27}$

Untuk mengukur daripada konsep diatas diperlukan indikator dari affiliate marketing. Indicator dari affiliate marketing adalah jumlah penjualan online, jumlah aktivitas transaksi, volume komisi, segmentasi, jumlah mitra dan afiliasi member baru. ${ }^{28}$ Enam indikator tersebut menggambarkan efektifnya kegiatan affiliate marketing pada perusahaan afiliasi. Oleh karena itu maka penting untuk diperhatikan bahwa siklus dan ekosistem afiliasi pada setiap item produk yang

\footnotetext{
${ }^{21}$ Suresh V et al., "A Study on Impact of an Affiliate Marketing in E-Business for Consumers' Perspective," International Journal of Engineering and Technology 10, no. 2 (2018): 471-75, https://doi.org/10.21817/ijet/2018/v10i2/181002050.

${ }^{22}$ Muhamim, "ANALISIS STRATEGI AFFILIATE MARKETING TERHADAP TINGKAT PENJUALAN DALAM PERSPEKTIF EKONOMI ISLAM(Studi Pada Butik Zoya Cabang Kedaton Bandar Lampung)."

${ }^{23}$ Ningsih, "Analisis Promosi Dan Affiliasi Marketing Terhadap Okupansi Hotel Non Jaringan Di Kota Batam."

${ }^{24}$ Ana Ramadhayanti, "Pengaruh Komunikasi Pemasaran Dan Affiliate Marketing Terhadap Volume Penjualan," Jurnal Komunikasi Bisnis Dan Manajemen 8, no. 1 (2021): 94-104, https://ojs.uniskabjm.ac.id/index.php/alkalam/article/view/4161.

${ }^{25}$ Ningsih, "Analisis Promosi Dan Affiliasi Marketing Terhadap Okupansi Hotel Non Jaringan Di Kota Batam."

${ }^{26}$ Patrick and Hee, "Affiliate Marketing in SMEs: The Moderating Effect of Developmental Culture."

${ }^{27}$ Ningsih, "Analisis Promosi Dan Affiliasi Marketing Terhadap Okupansi Hotel Non Jaringan Di Kota Batam."

${ }^{28}$ Benediktova and Nevosad, "MASTER'S THESIS Affiliate Marketing Perspective of Content Providers."
} 
ditawarkan khususnya pada perusahaan yang bergerak pada konsep dan mekanisme bagi hasil. ${ }^{29}$

\section{Metode Penelitian}

Penelitian ini adalah penelitian deskriptif yang mana tujuannya untuk memberikan suatu gambaran mengenai subjek penelitian berdasarkan data yang diperoleh dari subjek yang diteliti yang mana hal ini dilakukan untuk melakukan hipotesis. ${ }^{30}$ Teknik pengumpulan data yang digunakan peneliti menggunakan teknik observasi partisipatif aktif, menggunakan teknik purposive sampling serta teknik wawancara terstruktur. Pada penelitian ini peneliti mencantumkan subjek dan informan penelitian. ${ }^{31}$ Adapun untuk subjek-subjek dari penelitian ini yaitu member affiliate marketing Taqychan Saffron Palangka Raya yang masih bergabung guna untuk menanyakan hal-hal yang berkaitan tentang mekanisme bagi hasil affiliate marketing sebanyak 5 subyek. Informan pada penelitian ini ialah konsumen Taqychan Saffron yang bermukim di Kota Palangka Raya dan telah melakukan pembelian produk lebih dari sekali. Analisis penelitian dilakukan menggunakan teknis yang dikemukan oleh Miles dan Huberman yang dimulai dari pengumpulan data, reduksi data, penyajian dan penarikan kesimpulan. ${ }^{32}$

\section{Hasil dan Pembahasan}

\section{Mekanisme Affiliate Marketing}

Berdasarkan hasil penelitian yang dilakukan mulai dari observasi, wawancara dan dokumentasi yang penulis dapatkan bahwa mekanisme affiliate marketing pada Taqychan Saffron terdapat dua jenis referral di Taqychan Saffron yaitu melalui link dan kode referral. Pertama, link referral adalah link yang berbentuk alamat website yang disediakan oleh Taqychan Saffron untuk para member affiliate yang sudah resmi bergabung. Link ini terbagi menjadi 3 jenis yaitu ada link referral produk, link referral kategori produk, dan link referral sales page atau web utama Taqychan Saffron. Kedua, kode referral yang berbentuk kode atau kata yang dimasukkan oleh member di halaman registrasi. Member affiliate bisa memberikan kode referralnya kepada calon customers atau calon member ketika registrasi.

\footnotetext{
${ }^{29}$ Muhamim, “ANALISIS STRATEGI AFFILIATE MARKETING TERHADAP TINGKAT PENJUALAN DALAM PERSPEKTIF EKONOMI ISLAM(Studi Pada Butik Zoya Cabang Kedaton Bandar Lampung).”

${ }^{30}$ Sugiyono, Metode Penelitian Pendidikan Pendekatan Kuantitatif, Kualitatif, Dan R\&D (Bandung: Alfabeta, 2017).

31 Aguste Ferdinand, Metode Penelitian Manajemen (Semarang: Badan Penerbit Universitas Diponegoro, 2014).

${ }^{32}$ Sugiyono, Metode Penelitian Pendidikan Pendekatan Kuantitatif, Kualitatif, Dan R\&D.
} 
Program affiliate marketing Taqychan Saffron berisi panduan lengkap step by step bagaimana berbisnis online dan semua affiliate diberikan akses grup khusus. Hal yang dilakukan affiliate disini yaitu mempromosikan produk Taqychan Saffron dengan konten promosi yang telah disediakan, membagikan link website Taqychan Saffron dan membantu konsumen membeli dengan menggunakan kode referral affiliate untuk mendapatkan komisi.

Cara kerja affiliate marketing dengan membagikan link affiliasi/kode referral pribadi ke sosial media manapun. Setiap member diminta oleh system untuk membagikan link affiliasi sebagai cara kerja pertama. Kemudian, pengunjung mengklik link tersebut dan kemudian otomatis akan dibawa ke website resmi web.taqychansaffron.com. setalah masuk maka pengunjung membeli produk taqychan saffron melalui link yang telah dipromosikan. Setalah dilakukan pembelian dengan mengklik produk yang diinginkan maka produk akan dikirim dari distributor yang pembeli pilih ketika checkout. Affiliate mendapatkan komisi dari setiap produk yang berhasil terjual, akan dicairkan setiap awal bulannya.

Affiliate marketing ini menjadi solusi terbaik untuk mendapatkan profit atau penghasilan tambahan dimasa pandemi seperti sekarang. Apalagi bisnis digital ini menjadi salah satu bisnis yang hasilnya masih stabil tidak terpengaruh oleh adanya pandemi. Hal tersebut dikarenakan banyak orang mulai mencari peluang bisnis online yang bisa dikerjakan dirumah untuk hasilkan pendapatan tambahan.

Untuk menjadi member affiliate marketing Taqychan Saffron diharuskan untuk mendaftar akun di web Taqychan Saffron dengan mengisi data pribadi seperti nama, e-mail, nomor handphone, dan juga kata sandi untuk akun tersebut. Selain itu perlu memasukkan kode refferal supaya bisa mendaftarkan akun tersebut. Kode referral ini bisa didapat dari member affiliate yang sudah bergabung sebelumnya.

Jika akun sudah berhasil terdaftar, maka pilih join affiliate dan varian produk saffron yang ingin dibeli. Kemudian tambahkan alamat tujuan dan pilih distributor terdekat untuk menghemat biaya pengiriman. Selanjutnya klik beli sekarang, lanjut pembayaran, dan tertera nominal uang yang harus ditransfer sesuai jumlah yang tertera. Otomatis orderan akan segera diproses, setelah itu akan ada admin yang menghubungi untuk masuk ke grup telegram khusus (affiliate Taqychan Saffron).

Setelah resmi menjadi member affiliate, bisa langsung bergabung di grup telegram, menambah relasi dan sharing ilmu ke member yang lain, mendapatkan materi marketing, serta mendapatkan manfaat lainnya.

Kelebihan ketika bergabung menjadi affiliate marketing Taqychan Saffron yaitu sebagai berikut:

a. Bisnis mudah dikerjakan dan dimengerti, jam kerja fleksibel.

b. Tidak harus punya modal yang besar.

c. Hanya mempromosikan dan membagikan link website. 
d. Tidak ada persaingan harga dan tidak ada target penjualan di antara member.

e. Mendapatkan komisi $15 \%$ dari setiap transaksi pembelian melalui link yang dibagikan.

f. Setiap minggu rutin terdapat webinar tentang ilmu bisnis bersama mentormentor terbaik.

Terlebih dari kelebihan itu semua, tidak menutup kemungkinan adanya kekurangan dalam affiliate marketing ini. Setiap bisnis pasti ada kendalanya, tidak mungkin mulus seperti yang diharapkan. Akan tetapi setiap pebisnis ingin bisnis atau usahanya berjalan mulus tanpa adanya hambatan.

Kekurangan dalam affiliate marketing ini yaitu adanya kendala dalam mengakses website. Salah satu penyebabnya website overload sehingga menyebabkan performa website menjadi lambat bahkan berakibat tidak bisa diakses. Hal ini disebabkan karena pada saat pembukaan join affiliate atau pun diadakannya promo atau potongan harga produk Taqychan Saffron, pengunjung berbondongbondong mengakses website agar tidak kehabisan stok barang atau produk yang diinginkan.

Selain itu kendala dalam bisnis affiliate marketing ini yaitu betapa sulitnya untuk meyakinkan konsumen yang awam akan adanya saffron sebagai wasilah kesembuhan dan juga bagi kesehatan tubuh. Terlebih lagi harga saffron kashmir yang tidak murah. Hal ini dikarenakan setiap bunga saffron yang dipanen dipilih sendiri secara manual untuk diambil putiknya sehingga perlu adanya waktu yang lama. Maka diperlukan adanya tenaga kerja yang terampil untuk melakukan pekerjaan ini.

Faktor lainnya juga muncul tentang rumor yang beredar akan adanya saffron palsu dengan harga yang bisa dibilang sangat murah sekali. Jadi sebagai konsumen harus pintar memilih saffron walaupun belinya secara online tapi tetap perlu diingat harus teliti. Pastikan membeli dari sumber terpercaya dan terjaga kualitas serta keaslian saffron yang sudah terbukti memiliki izin BPOM dan juga dilihat dari review konsumen di marketplace.

\section{Bagi Hasil Affiliate Marketing Taqychan Saffron}

Sama dengaan banyaknya affiliate marketing lainnya, affiliate marketing Taqychan Saffron ini juga berbasis web. Demikian halnya juga dengan sistem bagi hasil otomatis melalui program web juga. Semua sudah terintegrasi oleh sistem di pusat, pembagian komisi dipastikan akurat dan sesuai oleh apa yang diusahakan.

Sistem bagi hasil disini dilakukan secara adil, jujur, transparan dan bertanggung jawab, tanpa adanya unsur kecurangan, gharar, ketidak-adilan dan unsur penipuan antar keduanya, karena biasanya sistem bagi hasil ini dilakukan menurut kesepakatan antara kedua belah pihak. Kedua belah pihak ini terikat 
kontrak kerja sama dalam suatu bisnis yang jika mendapatkan keuntungan maka akan dilakukan pembagian. ${ }^{33}$

Pada system afiliasi ini terlihat bahwa keuntungan di dapatkan dari penjualan dan promosi yang dilakukan oleh member yang terdaftar di Taqychan Saffron. Penyampaian informasi tersebut telah dijelaskan oleh Taqychan Saffron melalui situs web dan juga afiliasi member group. Untuk memastikan keadilan tercipta dalam system bagi hasil oleh Taqychan Saffron terkhusus untuk member maka Taqychan Saffron telah memberikan keterangan dan penjelasan baik secara langsung melalui group maupun melalui akun yang dimiliki. Komisi yang diberikan juga telah sesuai dengan apa yang diketahui oleh member yang terakomodir melalui system link yang terintegrasi melalui situs Taqychan Saffron. Hal tersebut telah sesuai dengan nilai-nilai ekonomi Islam yang mengutakan keadilan dalam proses transaksi ${ }^{34}$. Kemudian nilai lain juga telah diterapkan oleh Taqychan Saffron seperti jujur dan transparan. Taqychan Saffron telah memberikan keterangan secara jujur dan transparan. Informasi terkait komisi dan bonus telah diketahui oleh semua member sehingga tidak ada yang ditutupi oleh pihak Taqychan Saffron. Kejujuran tersebut tergambar dari informasi yang diberikan melalui situs website, kemudian dijelaskan Kembali dalam proses transaksi yang terlihat dari produk, distribusi, promosi, penjualan dan referral browser sehingga informasi tersebut mampu menjadi dasar bagi Taqychan Saffron untuk menerapkan nilai jujur dan adil dalam kegiatan afiliasi ${ }^{35}$. Terakhir adalah tanggung jawab dimana Taqychan Saffron telah bertanggung jawab dalam melakukan distribusi barang dan pembagian komisi. Karena Taqychan Saffron telah menggunakan system akrual maka system web terintegrasi dengan perbankan maka setiap adanya transaksi oleh member maka Taqychan Saffron akan melakukan pembayaran komisi secara realtime. Nilai ini juga telah dijelaskan dalam ekonomi Islam bahwa setiap akibat daripada kegiatan jual beli harus dapat dipertanggungjawabkan ${ }^{36}$.

Pada kegiatan bisnis affiliate marketing tidak sedikit terjadinya kecurangan. Kecurangan muncul dari beberapa factor seperti rendahnya pengetahuan member terhadap kondisi produk yang ditawarkan kepada konsumen, adanya pemaksaan kepada konsumen untuk membeli dengan menyampaikan kualitas produk terlalu berlebihan dan tidak adanya perbandingan produk sehingga menganggap produk sempurna tanpa ada catat. Meskipun begitu Taqychan

\footnotetext{
${ }^{33}$ Risanda Alirastra Budiantoro, Riesanda Najmi Sasmita, and Tika Widiastuti, "Sistem Ekonomi (Islam) Dan Pelarangan Riba Dalam Perspektif Historis," Jurnal Ilmiah Ekonomi Islam 4, no. 01 (2018): 1, https://doi.org/10.29040/jiei.v4i1.138.

${ }^{34}$ Euis Amalia, "Transformasi Nilai-Nilai Ekonomi Islam Dalam Mewujudkan Keadilan Distributif Bagi Penguatan Usaha Kecil Mikro Di Indonesia," Al-Iqtishad: Journal of Islamic Economics 3, no. 1 (2016), https://doi.org/10.15408/aiq.v3i1.2497.

${ }^{35}$ Rianto, Dasar-Dasar Ekonomi Islam.

${ }^{36}$ Muhamim, "ANALISIS STRATEGI AFFILIATE MARKETING TERHADAP TINGKAT PENJUALAN DALAM PERSPEKTIF EKONOMI ISLAM(Studi Pada Butik Zoya Cabang Kedaton Bandar Lampung)."
} 
Saffron telah memberikan garansi kepada member dan konsumen terhadap produk yang mereka tawarkan. Hal ini berarti dapat meminimalisir kecurangan yang pada akhirnya dapat membatalkan akad dalam transaksi dan juga ketidakpuasan member dan konsumen. Hal ini telah dijelaskan dalam system ekonomi Islam bahwa adanya larangan dalam bentuk kecurangan dalam kegiatan jual beli maupun kesepakatan akad muamalah ${ }^{37}$. Dalam bisnis Taqychan Saffron juga telah jelas tertera harga, kualitas dan komisi yang diberikan sehingga adanya kepastian. Kita tahu bahwa selama ini bisnis online banyak yang tidak memberikan keterangan pasti baik kualitas dari produk, harga yang cenderung berubah-ubah dan juga adanya ketidakpastian (gharar). Namun, kita tahu di Taqychan Saffron hal itu telah menjadi focus utama owner untuk memberikan edukasi terkait hal-hal yang tidak sesuai dengan nilai-nilai Islam. Islam selalu menginginkan adanya kepastian dalam bertransaksi yang dijelaskan terlebih dahulu sebelum dilakukannya jual-beli ${ }^{38}$.

Pada member Taqychan Saffron Palangka Raya selalu mengutamakan kejujuran. Oleh karenanya maka sampai saat ini belum pernah terjadi penipuan baik oleh member maupun oleh owner Taqychan Saffron. Penipuan yang dimulai dari ketidakpastian dan ketidakjujuran selalu dihindari oleh manajemen sehingga itu menjadi spirit Taqychan Saffron sebagai pelopor bisnis affiliate yang mengutamakan kejujuran dan keterbukaan informasi sesuai dengan nilai-nilai ekonomi Islam ${ }^{39}$.

Akad kerjasama yang digunakan oleh Taqychan Saffron menggunakan sistem mudharabah yaitu produk Taqychan Saffron yang dijual dikelola oleh affiliate untuk dipromosikan produknya dengan konten promosi yang telah disediakan. Kemudian hasil keuntungan dari penjualan produk ini setiap bulannya dibagi berdasarkan nisbah yang disepakati. Untuk harga produk saffron yang dijual mengikuti website web.taqychansaffron.com. Jika saat itu sedang mengadakan diskon potongan harga pada hari-hari tertentu, maka sebagai affiliate juga harus mengikutinya. la tidak bisa menaikkan harga semaunya karena itu sudah menjadi prosedur dari Taqychan Saffron. Tujuannya supaya tidak ada perang harga antara reseller dan member affiliate lainnya. Dengan menjadi member affiliate marketing Taqychan Saffron, affiliate harus menerima ketentuan dan kebijakan yang diterapkan oleh perusahaan Taqychan Saffron. Selain itu afiliate juga harus memberikan informasi atau spesifikasi produk yang sesuai yang akan dipromosikan supaya dipercaya oleh calon pembeli.

Setiap bulannya Taqychan Saffron ini juga mengadakan kontes untuk para member affiliate dengan penjualan terbanyak akan mendapatkan reward special. Kegiatan affiliate marketing Taqychan Saffron disini yaitu dengan menjual produk-

\footnotetext{
${ }^{37}$ Budiantoro, Sasmita, and Widiastuti, "Sistem Ekonomi (Islam) Dan Pelarangan Riba Dalam Perspektif Historis."

${ }^{38}$ Rahmawaty, "Bisnis Multilevel Marketing Dalam Perspektif Islam."

${ }^{39}$ Rianto, Dasar-Dasar Ekonomi Islam.
} 
produk melalui cara menyebarkan link dari website perusahaan tersebut. Dengan menyebarkan link referral tersebut kepada calon customers atau calon member, sehingga ketika nantinya mereka melakukan transaksi di Taqychan Saffron itu tercatat oleh sistem. Setelah itu sistem akan memberikan komisi kepada affiliate karena telah membantu menjualkan produk yang ada di Taqychan Saffron.

Selain itu bisa juga member affiliate membagikan link referral dengan menyertakan kode referralnya. Hal itu supaya calon customers yang transaksi melalui link yang telah dibagikan tersebut bisa terkunci datanya di data member pengikut di bawah affiliate karena sudah disertai dengan kode referral. Penjualan setiap produk taqychan saffron dari akun masing-masing pemasar jasa akan mendapatkan komisi $15 \%$. Selain itu ada $5 \%$ bonus royalti dari member yang telah direkrut dan mereka aktif berjualan. Maka itulah yang akan terhitung dalam jumlah rupiah yang akan ditransfer secara berkala setiap bulannya.

Taqychan Saffron tutup buku setiap tanggal 27, maka komisi pada tanggal 28 dan seterusnya itu masuk ke perhitungan bulan selanjutnya. Sistem bagi hasil antara perusahaan Taqychan Saffron dengan affiliate memiliki ketentuan dengan batas minimal transfer yaitu sepuluh ribu rupiah dengan metode pembayaran melalui bank BCA. Jika akun rekening affiliate menggunakan selain bank BCA, maka dikenakan biaya admin enam ribu lima ratus rupiah. Sehingga jika saldo komisinya dalam sebulan hanya sepuluh ribu belum termasuk dikurangi biaya admin, maka itu tidak akan mencukupi untuk bagi komisi. Sehingga dilakukanlah di bulan berikutnya hingga memenuhi ketentuan yang ada tersebut. Ini merupakan risiko yang diambil oleh member yang bisa dikatakan risiko likuiditas. ${ }^{40}$

\section{Penutup}

Affiliate marketing adalah sistem bisnis yang memberikan komisi kepada seorang affiliate ketika ia berhasil menjual produk atau jasa merchant (Taqychan Saffron) atau perusahaan yang mempunyai produk dengan pemasaran secara online melalui internet. Hal yang dilakukan affiliate disini yaitu mempromosikan produk Taqychan Saffron dengan konten promosi yang telah disediakan, membagikan link website Taqychan Saffron dan membantu konsumen membeli dengan menggunakan kode referral affiliate untuk mendapatkan komisi.

Sama dengan banyaknya affiliate marketing lainnya, affiliate marketing Taqychan Saffron ini juga berbasis web. Demikian juga dengan sistem bagi hasil otomatis melalui program web juga. Setiap penjualan setiap produk taqychan saffron dari akun pemasar jasa akan mendapatkan komisi $15 \%$. Selain itu ada $5 \%$ bonus royalti dari member yang telah direkrut dan mereka aktif berjualan. Maka itulah yang akan terhitung dalam jumlah rupiah yang akan ditransfer secara berkala setiap bulannya. Sistem bagi hasil antara perusahaan Taqychan Saffron dengan affiliate memiliki

\footnotetext{
${ }^{40}$ Isra Misra, Sofyan Hakim, and Agus Pramana, Manajemen Risiko (Yogyakarta: K-Media, 2020).
} 
ketentuan dengan batas minimal transfer yaitu sepuluh ribu rupiah dengan metode pembayaran melalui bank BCA.

Affiliate marketing adalah model bisnis dengan sistem pemberiaan fee atau komisi untuk jasa seseorang, setelah orang tersebut berhasil menjualkan barang melalui pemasaran di Internet. Hal yang dilakukan affiliate disini yaitu mempromosikan produk Taqychan Saffron dengan konten promosi yang telah disediakan.

\section{Daftar Pustaka}

Aguste Ferdinand. Metode Penelitian Manajemen. Semarang: Badan Penerbit Universitas Diponegoro, 2014.

Amalia, Euis. "Transformasi Nilai-Nilai Ekonomi Islam Dalam Mewujudkan Keadilan Distributif Bagi Penguatan Usaha Kecil Mikro Di Indonesia." Al-lqtishad: Journal of Is/amic Economics 3, no. 1 (2016). https://doi.org/10.15408/aiq.v3i1.2497.

Batu, Reminta Lumban, Tiar Lina Situngkir, Indah Krisnawati, and Sherliana Halim. "Pengaruh Digital Marketing Terhadap Online Purchase Decision Pada Platform Belanja Online Shopee." Ekonomi \& Bisnis 18, no. 2 (2020): 144-52. https://doi.org/10.32722/eb.v18i2.2495.

Benediktova, Barbora, and Lukas Nevosad. "MASTER'S THESIS Affiliate Marketing Perspective of Content Providers," 2008.

Budiantoro, Risanda Alirastra, Riesanda Najmi Sasmita, and Tika Widiastuti. "Sistem Ekonomi (Islam) Dan Pelarangan Riba Dalam Perspektif Historis." Jurnal IImiah Ekonomi Islam 4, no. 01 (2018): 1. https://doi.org/10.29040/jiei.v4i1.138.

Ekonomi, Jurnal, Hukum Ekonomi, and Masyarakat Membeli Sukuk. "ALIQTISHADIYAH" 6 (2020).

Ali Sadikin Isra Misra, dan Muhammad sholehuddin. Pengantar Manajemen Dan Bisnis. Yogyakarta: K-Media Publiser, 2020.

Isra Misra, Muhammad Ragil dan Muhammad Iqbal. Manajemen Perbankan Syariah. Yogyakarta: K-Media Publiser, 2021.

Mandelbaum, Ron, and Amos Zehavi. "Recession as a Window of Opportunity for Public Sector Recruitment." Policy Studies 35, no. 2 (2014): 115-30. https://doi.org/10.1080/01442872.2013.875142.

Misra, Isra \& Arianto. "Pengaruh Dimensi Kualitas Pelayanan Jasa Terhadap Kepuasan Dan Minat Datang Kembali Konsumen Pada Dealer Wira Megah Toyota Profitamas Palangka Raya Isra Misra 1." Al-Qard Vol 3, no. 1 (2018): 112. palangkaraya.ac.id/index.php/qardh/article/view/1181.

Misra, Isra, Sofyan Hakim, and Agus Pramana. Manajemen Risiko. Yogyakarta: KMedia, 2020.

Misra, Isra, and Ali Sadikin. "Nilai-Nilai Ekonomi Islam Dalam Tradisi Malan” 17, no. 
01 (2021): 72-82. https://doi.org/10.23971/jsam.v.

Muhamim, Ahmad. "Analisis Strategi Affiliate Marketing Terhadap Tingkat Penjualan Dalam Perspektif Ekonomi Islam(Studi Pada Butik Zoya Cabang Kedaton Bandar Lampung)," 2017. http://repository.radenintan.ac.id/319/.

Ningsih, Desrini. "Analisis Promosi Dan Affiliasi Marketing Terhadap Okupansi Hotel Non Jaringan Di Kota Batam" 8, no. 1 (2019): 125-34.

Patrick, Zurina, and Ong Choon Hee. "Affiliate Marketing in SMEs: The Moderating Effect of Developmental Culture." Pertanika Journal of Social Sciences and Humanities 29, no. 2 (2021): 1249-71. https://doi.org/10.47836/pjssh.29.2.27.

Rahmawaty, Anita. "Bisnis Multilevel Marketing Dalam Perspektif Islam." Marketing, 2013, 77-94.

Ramadhayanti, Ana. "Pengaruh Komunikasi Pemasaran Dan Affiliate Marketing Terhadap Volume Penjualan." Jurnal Komunikasi Bisnis Dan Manajemen 8, no. 1 (2021): 94-104. https://ojs.uniskabjm.ac.id/index.php/alkalam/article/view/4161.

RI, Departemen Agama. Al-Qur'an Dan Terjemahnya. Jakarta: Proyek Pengadaan Kitab Suci Al-Quran KEMENAG, 2015.

Rianto, Nur. Dasar-Dasar Ekonomi Islam. Solo: Era Adicitra Intermedia, 2017.

Situmorang, James R. "Pemasaran Viral Â€" Viral Marketing." Jurnal Administrasi Bisnis Unpar 6, no. 1 (2010): 63-75. https://doi.org/10.26593/jab.v6i1.369.

Sugiyono. Metode Penelitian Pendidikan Pendekatan Kuantitatif, Kualitatif, Dan R\&D. Bandung: Alfabeta, 2017.

V, Suresh, Vetri Selvi M, Maran K, and A.R.Shanmuga Priya. "A Study on Impact of an Affiliate Marketing in E-Business for Consumers' Perspective." International Journal of Engineering and Technology 10, no. 2 (2018): 471-75. https://doi.org/10.21817/ijet/2018/v10i2/181002050. 